\title{
Physico-Chemical, Microbiological Profiles of Blends of Tea and Mistletoe - a Highly Medicinal Mix
}

\author{
Akinwale, T.O., Aroyeun, S.O. and Obatolu, C.R \\ Cocoa Research Institute of Nigeria
}

\begin{abstract}
Sample of tea obtained from Mambilla, Nigeria highland was blended with mistletoe - a known medicinal parastic plant of cocon. The ratios of the blends were Tea(M)Mlatietoe (M) 90:10 10:90, 75:25, 25:75, and 50:50 while ordinary tea and mistletoes served as control samples. Chemical analyses of blends were done followed by organoleptic ascessment and microbial analysis. The chemical analyses indicated a higher value of $16.52 \%$ ash for mistletoes than tea which was $4.93 \%$ and this value increased with increased level of mistletoe in the blends. Blends were found to vary in alkolinity of ash (AA), water soluble ash (WSA) acid insoluble ash (ALA), moisture content and total ash. The low fungal count recorded in the fresh state of mistletoe and tea was as a result of adequate drying of the leaves. Sensory analysis carried out indicated that at $5 \%$ significant bevel, there were difierences in the attributes of colour, taste, Mavour and overall acceptability. In all the blends, the control sample (Tea) was highly rated followed by the sample containing $90 \%$ of tea blended with $10 \%$ of mistletoe.
\end{abstract}

\section{Introduction}

Most of the work done on tea have been centred on soil requirements, farming systems, plant breeding and so on. A study was carried out on the processing, quality assessment and utilization of tea and by-products (Ogunmoyela, 1982); it was observed after the investigation that clone 35 and 318 appeared to be most phosphorus deficient with means of $0.21 \%$ and $0.23 \%$ respectively. It was recommended, however, that nutrient status of the tea leaves should be improved and that since all cones were deficient in calcium and magnesium, there should be an enhancement of the nutritional status of tea by fortification or by blending. Obatolu (1987), carried out an investigation on 10 clonal selections of tea seeds received from Mambilla substation and their quality indices were analyzed for moisture content, total ash and crude fat. The analysis indicated that the seed kernel contains $22.15 \%$ crude fat, $3.22 \%$ total ash and $57.49 \%$ moisture content. Adesioye (1990) in his investigative studies on the quality assessment of locally grown tea and the diversification of utilization of its by products reported that the tea kernel contained 1.46 refractive index, $0.88-0.99 \mathrm{~g} /$ ml by density, $18.64-37.71 \%$ crude fat, 3.28 $350 \%$ crude fibre and $0.81-0.97 \%$ free fatty acid. The results of these physicochemical analysis showed the potential of tea kernel-oil as an edible oil. Studies on Mayo-Selbe lowland tea adaptation where the rate of survival of about four tea clones were investigated including the analysis of soil of tea plots (Obatolu,
1995). Parameters like $\mathrm{pH}$, total nitrogen)available phosphorus, calcium and other exchangeable cations were determined. These were measurable parameters of consideration for utilization of tea products.

It was important to diversify the product range of tea as a health food drink to include medicinal preparations (Jeremiah 1995), and other forms of beverages like instant tea, tea cola and iced tea. Research into the diversification of tea products could open up other markets, and thus help to improve demand and profits of tea farming (Owuor, 1988, 1989, 1992).

However, the state of research on tea regarding the health aspect is limited and the majority of work has been conducted on green tea and little on black tea (Jeremiah, 1995). Considerations of mistletoe blended with tea sample served as a medicinal mix for hypertension (Kafan, E. 1994) The objective of this work was to investigate the chemical composition of tea and mistletoe blended in different ratios and assess the consumer acceptability of the blends in order to detect the best desirable blend ratio.

\section{Materials and Methods}

The material used in this analysis comprised of samples of tea obtained from the highland of Cocoa Research Institute of Nigeria, Mambilla. Mistletoe was obtained on cocoa plots at CRIN, Onigambari, Ibadan, Oyo State, Nigeria.
All the laboratory apparatus and reagents used were procured from the Crop Processing and Utilization Unit of Cocca Research Institute of Nigeria, Ibadan.

Samples Preparation: The tea samples were divided into four portions and each of the four parts was blended with mistletoe at different levels in the ratio of $75: 25,50: 50,90: 10,25: 75$ and 10:90 of tea and mistletoe respectively. Control samples were tea samples and mistletoe. All the different blends were subjected to the same chemical and physical analyses. Only microbiological analyses of mistletoe and tea were done.

Brewing of Sample of Tea and Mistletoe Blends: About $6 \mathrm{~g}$ of each sample was dissolved in $200 \mathrm{ml}$ of hot water, filtered and preserved for analysis.

Sensory Analysis: The brewed samples were presented to group of 15 assessors without sugar. The attributes of colour. taste, flavour and general overall acceptability were determined using 9 point hedonic scale with 1 - indicating dislike extremely and 9 - like extremely. The results were later on subjected to statistical analysis using TURKEY's test for the determination of least significant difference in the attributes of colour, flavour, taste and general acceptability. Water extract determination, water soluble ash, acid insoluble ash, alkalinity of ash. Tannin and caffeine determinations were all done according to (AOAC, 1980) methods. 
Tannin Determination: About $5 \mathrm{~g}$ of sample was boiled for 30 minutes with $400 \mathrm{ml}$ of water and cooled before being transferred to $500 \mathrm{ml}$ volumetric flask followed by dilution to volume, $25 \mathrm{ml}$ of indigo carmine solution was added with about $750 \mathrm{~m} 1$ of water. Potassium tetraoxomanganate (VI) solution was added from the burette little at a time while stirring until the solution became light green, then dropwise until the colour changed to bright yellow at the end point. The volume of the KMnO (Potassium Tetraoxomanganate VII) used was designated as $\mathrm{x}$. About $100 \mathrm{ml}$ gelatin solution, $100 \mathrm{ml} \mathrm{NaCl}$, and $10 \mathrm{~g}$ of powdered kaolin were added together in a stoppered flask, shaken several times and allowed to settle followed by decanting. $25 \mathrm{ml}$ of the filtrate was later mixed with $25 \mathrm{ml}$ indigo carmine solution and about $750 \mathrm{ml}$ water followed by titration with $\mathrm{KmnO}_{4}$ solution. $\mathrm{MI} \mathrm{KmnO}_{4}$ used was subtracted from that obtained above, this gave the quantity of $\mathrm{KmnO}_{4}$ required to oxidize tannin. (1ml $0.1 \mathrm{~N}$ oxalic acid $=0.0042 \mathrm{~g}$ tannin.)

Caffeine Determinations: About 20mI of tea extract was mixed with $50 \mathrm{ml}$ of water in a $100 \mathrm{ml}$ volumetric flask. $5 \mathrm{ml}$ of zinc ferrocyanide clearing agents was added, diluted to the mark and shaken. The solution was allowed to stand for 5 minutes before being filtered through rapid filter paper. The volume of the filtrate was then measured and transferred to the separator, about $10 \mathrm{ml}$ of $0.88 \mathrm{~m}$ ammonia extract was added 5 times with $25 \mathrm{~m} 1$ portions of chloroform. The bulk extracts were shaken first with $10 \mathrm{ml}$ of $\mathrm{M}$ sodium hydroxide solution and then with $10 \mathrm{ml}$ of water. The liquors were shaken with little chloroform and added to the lower layer to the bulk chloroform extract. The chloroform was filtered into a weighed flask. The solvent was distilled off, dried at $100^{\circ} \mathrm{C}$ and weighed for caffeine.

Fungal Counts: About $6.5 \mathrm{~g}$ of Sarbouraud Dextrose Agar was dissolved in $100 \mathrm{ml}$ of distilled water. The solution was thoroughly heated. The solution was then transferred to the autoclave for sterilization at $121^{\circ} \mathrm{C}$ for 15 minutes. Samples of tea and mistletoe were weighed (about $1 \mathrm{~g}$ ) and introduced into $9 \mathrm{ml}$ sterilized distilled water in test tubes followed by serial dilutions to 10 . About $1 \mathrm{ml}$ of the diluent was added to $9 \mathrm{ml}$ of the Sabouraud dextrose agar. The solution were mixed thoroughly and allowed to cool and solidify. The plates were then incubated at $25^{\circ} \mathrm{C}$ for 7 days for yeasts or fungi. Fungal counts were done using colony counter.

Acidity Determination: $1 \mathrm{ml}$ of each of the test samples was dissolved in $9 \mathrm{ml}$ of water and the solution was titrated against $0.1 \mathrm{NNaOH}$ using phenophthalein as indicator.

\section{Results and Discussion}

From Table 1, the general overall $\mathrm{pH}$ of all the samples tend towards acidity, except for mistletoe having a $\mathrm{pH}$ greater than 7 and hence showing a basic alkaline tendency. The greater the percentage inclusion of mistletoe in the blend as indicated, the higher the $\mathrm{pH}$ and the greater the alkalinity tendency of the infused liquor.

The presence of certain chemical compounds in varying amounts and proportions have been suggested as indicators of made tea quality (Owuor $e t$ al, 1987; Ramaswany, 1962). Certain compounds like tannin and caffeine levels of tea and mistletoe were shown in Table 2 , with the caffeine content being $2.3 \%$ for tea, while the tannin content of tea and mistletoe were $0.6 \%$ and $0.23 \%$ respectively. The percent caffeine value of tea was comparable to the range reported by Nigeria industrial standard for tea (1998) as $1.9-3.6 \%$. The tannin contents as reported therein were considerably lower (Table 2). Other parameters of importance for tea include: water soluble ash, acid insoluble ash, alkalinity of ash, moisture content and ash. The ash content of mistletoe was very high $(16.52 \%)$ indicating that mistletoe contains more minerals than tea having ash content value of $4.98 \%$, this was a little higher than $3.22 \%$ as reported by (Obatolu 1989). This might be due to the soil composition and the processing practice employed. The moisture content of $57.49 \%$ was higher probably as a result of post harvest storage in humid environment, but moisture content recorded in Table 2 is $13.3 \%$. This value was higher than the one reported by NIS (1998) The stimulating effect of tea beverage is due to its caffeine contents (Cloughley 1982), (Owuor et al 1987). Caffeine is known to be a central nervous system stimulant (Werkehoven, 1974) and its role in black tea quality has been acknowledged by many workers (Owuor et al. 1987). The leaf quality and processing practices, particularly withering and fermentation influenced the production of this compound during black tea processing.

There were variation in the values obtained for ash, moisture content, extractives, acidity, alkalinity of ash, water soluble ash and acid insoluble ash. In all the blends ratio is an index of the chemical value. (Table 2). The higher the amount of mistletoe in the blend, the greater the

Table 1. Some chemical characteristics of Tea, Mistletoe and the various blend of tea and Mistletoe.

\begin{tabular}{|c|c|c|c|c|c|c|c|c|c|}
\hline \multirow[t]{2}{*}{ Samples } & \multicolumn{7}{|c|}{ Chemical charateristics (\%Average) } & \multirow[t]{2}{*}{ Tannin } & \multirow{2}{*}{$\begin{array}{c}\text { Extractive } \\
(\%)\end{array}$} \\
\hline & Moisture & $\mathrm{pH}$ & Ash & Alkalinity & $\begin{array}{c}\text { Water } \\
\text { soluble } \\
\text { Ash }\end{array}$ & $\begin{array}{l}\text { Acid } \\
\text { soluble } \\
\text { ash } \\
\end{array}$ & Caffeine & & \\
\hline Tea (T) & $2.13^{\mathrm{e}}$ & $5.70^{6}$ & $4.39^{8}$ & $0.31^{\mathrm{d}}$ & $6.35^{c}$ & ND & 2.30 & $0.60^{2}$ & $60.00^{4}$ \\
\hline Mistletoe & $3.30^{b}$ & $7.60^{\mathrm{a}}$ & $16.52^{b}$ & $0.56^{b}$ & $3.40^{f}$ & ND & ND & $0.23^{b}$ & $21.00^{\circ}$ \\
\hline $90 \mathrm{~T}: 10 \mathrm{M}$ & $3.30^{b}$ & 5.30 & $6.72^{f}$ & $0.16^{f}$ & $4.50^{e}$ & $5.22^{d}$ & ND & $0.04^{\mathrm{e}}$ & $52.10^{b}$ \\
\hline $75 \mathrm{~T}: 25 \mathrm{M}$ & $3.27^{\mathfrak{c}}$ & $5.60^{b}$ & $8.60^{\mathrm{e}}$ & $0.28^{e}$ & $6.80^{6}$ & $7.54^{8}$ & ND & $0.14^{c}$ & $48.40^{\circ}$ \\
\hline 50T:50M & $2.70^{d}$ & $5.90^{6}$ & $11.14^{d}$ & $0.78^{\mathrm{a}}$ & $5.3^{d}$ & $4.52^{e}$ & $\mathrm{ND}$ & $0.23^{b}$ & $42.10^{4}$ \\
\hline $25 \mathrm{~T}: 75 \mathrm{M}$ & $3.30^{b}$ & $6.00^{a b}$ & $12.82^{c}$ & $0.36^{d}$ & $7.8^{\prime \prime}$ & $8.00^{b}$ & $\mathrm{ND}$ & $0.08^{d}$ & $16.50^{5}$ \\
\hline $10 \mathrm{~T}: 90 \mathrm{M}$ & $3.60^{2}$ & $6.30^{a b}$ & $17.20^{2}$ & $0.40^{\mathrm{c}}$ & $4.73^{e}$ & $10.44^{\mathrm{a}}$ & ND & $0.02^{\mathrm{f}}$ & $12.10^{8}$ \\
\hline
\end{tabular}

$a, b, c, d, e, f, g-m e a n s$ in this column with different letters are significantly different $(P<0.05)$

ND - Not done

Table 2. Organoleptic profiles of tea blends

\begin{tabular}{lccccccc}
\hline & $(\mathrm{a})$ & $(\mathrm{b})$ & $(\mathrm{d})$ & $(\mathrm{e})$ & $(\mathrm{g})$ & $(\mathrm{c})$ & $(\mathrm{f})$ \\
\multicolumn{1}{c}{ Attributes } & 412 & 107 & 311 & 788 & 922 & 833 & 285 \\
\hline Taste & 6.67 & $5.87 \mathrm{ab}$ & $5.80 \mathrm{ab}$ & $5.67 \mathrm{ab}$ & $5.53 \mathrm{ab}$ & $5.13 \mathrm{~b}$ & $4.87 \mathrm{bc}$ \\
Flavour & $6.07 \mathrm{a}$ & $4.87 \mathrm{c}$ & $5.73 \mathrm{ab}$ & $5.68 \mathrm{ab}$ & $5.80 \mathrm{ab}$ & $5.87 \mathrm{ab}$ & $5.53 \mathrm{~b}$ \\
Colour & $6.67 \mathrm{a}$ & $4.87 \mathrm{bc}$ & $5.13 \mathrm{~b}$ & $5.68 \mathrm{ab}$ & $5.80 \mathrm{ab}$ & $5.87 \mathrm{ab}$ & $5.53 \mathrm{~b}$ \\
Overall & $6.73 \mathrm{a}$ & $5.00 \mathrm{c}$ & $5.85 \mathrm{ab}$ & $5.68 \mathrm{ab}$ & $5.13 \mathrm{ab}$ & $6.20 \mathrm{ab}$ & $5.13 \mathrm{~b}$
\end{tabular}

acceptability

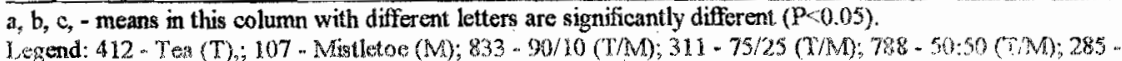
$25 / 75(\mathrm{~T} / \mathrm{M}) ; 922 \cdot 10 / 90(\mathrm{~T} / \mathrm{M})$ 
Thible 3. Viable rungal counts (Propagules/g of tea and Mistletoe)

\begin{tabular}{lllll}
\hline & \multicolumn{3}{c}{ Dilutions/Count } \\
\cline { 2 - 5 } Samples & $10^{-1}$ & $10^{-2}$ & $10^{-3}$ & $10^{-4}$ \\
\hline Tea & 14 & 11 & 8 & No growth \\
Mistletoe & 16 & 8 & 3 & 2 \\
\hline
\end{tabular}

ash and the moisture content while extractives increased with increase in the tea in a particular tea/mistletoe blend. The low fungal count recorded was as a result of adequate drying of both the tea and mistletoe leaves (Table 3).

In conclusion, mistletoe can be blended with tea to make a health drink in the ratio TIM 90:10, 75:25 and 50:50, however the ratio of $90: 10$ (Tea/mistletoe) was acceptable to consumers.

The organoleptic profiles of different tea as shown in Table 3 indicated that the quality of black tea referred to all the characters such as colour, taste, aroma by which it may be judged for its market value (Ramaswamy 1964). In all, black tea quality is a summation of all its desirable attributes (Werkhoven 1974).

As shown in the tables, there were significant differences in all the attributes of colour, taste, flavour and overall acceptability. The control sample (Tea) was the most highly rated in all the attributes. The sample containing $90 \%$ of tea blended with $10 \%$ of mistletoe was the next highly rated. The sample with (50:50) of tea and mistletoe was equally acceptable to the assessors in terms of colour, flavour and general acceptability. The least ranked by panelists is the ordinary mistletoe. This is an indication that mistletoe taken ordinarily, cannot be compared to ordinary tea in all the desirable attributes. However, the blend of tea with mistletoe will improve the acceptability of the product as a health drink.

\section{References}

Adesioye, H.0. (1990). Quality assessments of locally grown Tea and the diversification of it's by products. CRIN's Annual Reports pp.6465 .

AOAC (1990). Association of Analytical Chemists. Official method of Analysis Washingtong DC USA.

Cloughley, J.B. (1982). Factors influencing field variables. Food Chemistry, 9, 269-276.

Jeremiah, K.R. (1995). The research mandate, accomplishments and Priorities of the Tea Research Foundation of Kenya - A review Tea, 16(1) Pgs.48-61. caffeine content of black tea. Part I - Effect of

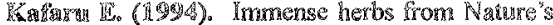
Workshop, Bublisher:

Elikahe healuh Services Limited printed by Academy Press Plc. Pgs.69-72, NIS (1998). Nigerian Industrial Standard. Revised edition for Tea.

Standard Organization of Nigeria, Federal Secretariat Complex, Ikoyli, Lagos.

Obatolu, C.R. (1989). Improvement of Tea Production and Propagation "Enhancement of germplasm materials" CRIN Annual Reports pp. 83

Obatolu, C.R. (1995). Problems of establishment and management of Tea. CRIN Annual Reports pp. 60-61.

Ogunmoyela, 0.A. (1982). Processing, Quality assessments and Utilization of Tea and it's by products. CRIN Annual Reports pp. 40. 41 .

Owuor, P.O., Horita, H., Tsusluda, T. (1987) Variations in the chemical composition of Kenyan clonal tea. Kenyan J. Sci. Tech. Series A.

Owuor, P.O., Mutea, M.J.S., Obanda, M.A. and Reeves, S.G. (1986). Effects of withering on some quality parameters of black tea. Preliminary results. Tea 7(1): 13-17.

Ramaswamy, M.S (1962). Chemical basis for liquoring characteristics of Ceylon Tea liquors Tea Quarterly 33:156-165.

Ramaswamy, M.S. (1964). The effects of evaluation and climatic conditions on the Tea liquors. Tea Quarterly 35:164.

Werkhoven J. (1974). Tea Processing F.A.O Agric. Bulletin: 12:9-23. 